\title{
AZ ARKHIMÉDÉSZI SPIRÁL FOGIRÁNYVONALÚ HENGERES FOGASKEREKEK BURKOLÁSÁNAK A BURKOLT FELÜLETSEREG ELOSZTÁSÁT JELLEMZŐ ASPEKTUSÁRÓL
}

\section{ASPECTS OF THE REPARTITION OF THE MESHED SURFACE MANIFOLD BY THE MESHING PROCESS OF CYLINDRICAL GEARS WITH ARCHIMEDEAN SPIRAL SHAPED TOOTHLINE}

\author{
Máté Márton ${ }^{1}$, Hollanda Dénes ${ }^{2}$ \\ Sapientia Erdélyi Magyar Tudományegyetem, Müszaki és Humán Tudományok Kar, \\ Gépészmérnöki Tanszék, 540485 Târgu Mureş, O.p. 9, C.p. 4., Telefon/Fax:+40- \\ 265-206210, ${ }^{1}$ mmate@ms.sapientia.ro, ${ }^{2}$ hollanda@ms.sapientia.ro
}

\begin{abstract}
Manufacturing cylindrical gears with curved teeth is motivated by the purpose of increasing the load capacity. It is demonstrated that pairing of concave and convex tooth flanks leads to significant increasing of the bearing capacity of gear pair. The peculiar aspects of the kinematics regarding the generating of the curved teeth of the cylindrical gear cannot be described using the bi-parametrical meshing model. This drawback was eliminated through the model of the pulsating generating rack. Just solving the equation of gearing isn't sufficient, because the phenomenon of ante- and post-trimming cannot be identified through that. This aspects can be handled analyzing the relative kinematics at the level of the cutting edge. The study of the real generating surfaces is difficult due to the rugged distribution of the generating surfaces.

This paper presents the mathematical model of an alternative solution. The peculiarity of the proposed method consists in focusing on the repartition of the curves- resulted as traces of the cutting edge when this traverses a family of parallel planes disposed perpendicular to the gear's axis. Through this the spatial meshing will be reduced to $n$ parallel plain curve meshing processes.
\end{abstract}

Keywords: Cylindrical gear, spiral, meshing, family of curves.

\section{Összefoglalás}

A görbe vonalú hengeres fogaskerekek előállításának célja a terhelhetőség növelése. Bizonyított tény, hogy a konvex-konkáv kapcsolódó fogfelület-párosítás a terhelhetőség jelentős növelését eredményezi. A közleményben szereplö fogaskerék lefejtés-kinematikájának sajátos aspektusai a kétparaméteres burkolás modelljével nem írhatók le, ezért bevezettük a pulzáló fogasléc modelljét. A kapcsolódási egyenlet megoldása nem elegendő, ugyanis ki kell zárni az elö-, illetve az utólenyesés jelenségét. Ez a relatív mozgás vágóélszintre lehozott kinematikájának részletes elemzésével valósul meg. A valós generáló felületek eloszlása annyira egyenetlen, hogy a burkolás tanulmányozása nehézkessé válik.

Jelen közleményben az elöbb jelzett hátrány kiküszöbölésére kidolgozott alternatív módszer matematikai modelljét mutatjuk be. A módszer sajátossága abban áll, hogy a burkolt kerék tengelyére merőleges síkokban keletkező görbeseregek relatív elhelyezkedését vizsgáljuk.

Kulcsszavak: hengeres fogaskerék, spirális, burkolás, görbesereg 


\section{A fogazat lefejtésének elve}

Az Arkhimédész-féle spirális fogirány vonalú hengeres fogaskerekek alternatívát jelentenek az ismert Wildhaber-Novikov típusú egyenes vagy ferde fogú hengeres fogaskerekekre. A célunk létrehozni olyan, helyesen kapcsolódó külső, hengeres hajtópárt, amely az erőátadást konvex-konkáv fogoldalak között valósítja meg. A Wildhaber-Novikov-fogazat a fogprofil magasságában konvex-konkáv, és igen érzékeny a tengelytáv-módosításra [3,4]. A javasolt hajtópár esetében a fogoldalak konvex-konkáv jellege az Arkhimédész-féle spirális vezérgörbe miatt alakul ki. A lefejtés elméletileg egyetlen származtatófelülettel történik, Olivier első fogazási módszere szerint [1]. A tangenciális előtolásos lefejtés elvét az 1. ábrán szemléltettük. A lefejtő szerszám egy $Z_{0}=3$ késcsoportból álló, egyenként 3-5 kést tartalmazó, az „Öerlikon”-féle marófejekhez igen hasonló felépítésü, a kések mikron pontosságú radiális állítását megengedő marófej. A késprofilok középpontjai (az osztóvonal és a fogprofil szimmetriavonalának metszéspontja) Arkhimédész-féle spirális vezérgörbére illeszkednek. Az 1. ábra alsó vázlata a felülnézet, ahol jól látható a 3 Arkhimédészféle spirális ív. A szerszám forgása miatt ennek tengelysíkjában egy pulzáló fogasléc jön létre $[9,10]$, melynek elmozdulását két szuperponált mozgás adja: az első, gyors mozgás a spirális hatása miatt jön létre, és addig tart, ameddig a vizsgált késcsoport része a fogaskereket határoló, ennek tengelyére merőleges síkok között található vagyis attól a pillanattól, hogy a késcsoport első kése begördül, az utolsó pedig kigördül az említett síkok közül. Az 1. ábrán a virtuális fogaslécszelvényt a fogaskereket szélességében felező síkban szemléltetjük. Mivel ez a mozgás terjedelmében igen rövid, a léc nem képes ,befutni” akkora távot, hogy a teljes fogaskerék-fogprofillal kapcsoljon.
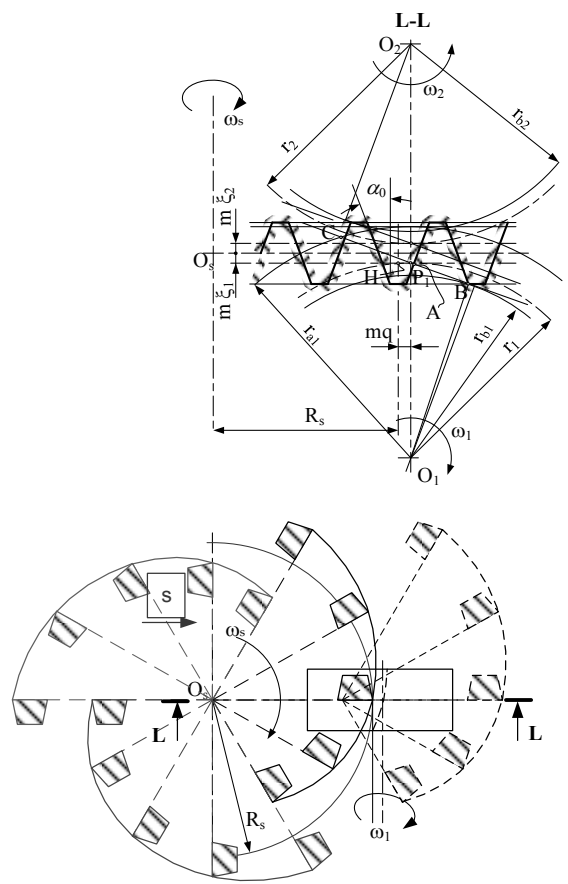

1. ábra. A tangenciális elötolásos fogazatlefejtés elve

Ezen tangenciális előtolással segítünk, vagyis a szerszám tengelye sugárirányban elmozdul. A fogaskerék eközben saját tengelye körül állandó szögsebességü forgómozgást végez, aminek következtében a görbült fogú, de szabályos profilú fogasléc kigenerálja a fogárkot.

A fogárokban egyszerre egy késcsoport dolgozik, vagyis a kerék egy szögosztásnyi elfordulására a marófej $2 \pi / Z_{0}$ értékű központi szöggel fordul el. Miután a fogaskerék vizsgált fogárka ismét lefejtési helyzetbe kerül, a marófej valamelyik késcsoportja a tangenciális előtolás hatására már elöretolt helyzetben található, így a pulzálás (a gyors mozgás) a fogaskerék tengelyéhez 
már közelebb történik. Az elöbb ismertetett geometriai sajátosságok alapján kijelenthetjük, hogy a lefejtés diszkrét, egymás után következő fogasléc-fogaskerék kapcsolódási helyzetekből mint kiinduló helyzetböl kezdődő, részleges legördülések halmazaként fogható fel.

A módszer egy korábbi változata radiális behatolással megvalósított [2]. Ennél a változatnál a szerszám inkább a „Mammano”-féle maróhoz hasonlít. A tangenciális elötolásos módszer több hordképlokalizációs lehetőséget rejt, és nagyobb várható termelékenységet ígér.

Mind a radiális behatolással történő lefejtés, mind a tangenciális előtolásos módszer esetében nemcsak a szerszám felépítéséből származó előnyös foggörbületkialakítást (a kések radiális elmozdítása), hanem a fogasléc egyenes profilja adta általános fogazási lehetőségeket is hatékonyan ki lehet használni a hordkép kialakítására [6].

A burkoláshoz szükséges kapcsolódási egyenletet kétparaméteres vagy egyparaméteres burkolásként is fel lehet írni $[1,5]$. A numerikus kiértékelés során a [7,8]-ban is említett módszerekhez hasonló módszert alkalmaztunk.

A kapcsolódási egyenlet kimutatja a kapcsolódási pontokat adott pillanatban, adott helyen, és emellett a szinguláris pontokat is. Azt azonban nem mutatja ki, hogy a kapcsolódási egyenletet kielégítő felületpont meg is marad. Lehetséges, hogy az adott pontot a szerszám már azelőtt lesodorja, hogy valósan kapcsolódna (elölenyesés), vagy pedig a már kigenerált pontot egy újabb pulzáláskor forgácsba söpri (utólenyesés).

A generálás elméleti alapját a folytonos, azaz végtelenül sok vágóélet tartalmazó szerszámfogcsoport adja. A valóságban azonban a fogcsoportnak véges számú (3-5) tagja van, így a valós származtató felületsereget az egyes kések élei írják le a fogaskerékhez viszonyított relatív mozgás során.
A valós felületsereg végtelenítéséhez feltételezni kell, hogy a tangenciális előtolás értéke a nulla felé tart, így mindenik késél egyszerü végtelenségnyi felületet ír le. A burkolófelület $z_{s}$ végtelenségnyi felületnek burkolójaként keletkezik. A kérdés az, hogy az $i$-edik végtelenségnyi felületsereg burkolója metszi-e, avagy kiegészíti a $j$-edik felületsereg burkolóját. A felületek vizualizálása rámutatott arra, hogy elhelyezkedésük és alakjuk erösen függ a virtuális léc és a fogaskerék relatív helyzetétől. A könnyebb átláthatóság végett a burkolást a fogaskerék tengelyére merőleges, véges számú síkszeletben tanulmányozzuk, majd pedig az egyes szeletekben keletkező burkológörbékre írjuk fel a fogazatot kielégítő módon közelítő spline-fogfelületet.

\section{A késcsoport felépítése}

A jelen elemzésben $Z_{0}=3$ késcsoportos és csoportonként $z_{s}=5$ betétkéses marófejet tekintünk, amelyik egyetlen fogárokban dolgozik. Az ellenkereket megmunkáló szerszám értelemszerüen $[1,5]$ a fogaskerék fogát öleli körül. Tehát a konkáv és konvex oldalak kései két, egymás után következő fogárokban fognak dolgozni.

A kések profilja elméletileg a generáló fogasléc profiljával és méreteivel megegyező. A valóságban a csoport első kése a nagyolókés, tehát mindkét éle aktív, míg a csoport többi kése felváltva vág a konkáv, illetve a konvex fogárokoldalon. Feltételezzük, hogy a késcsoport számára kijelölt központi szögtartomány valamivel kisebb, mint az elméleti felosztás:

$$
\psi_{0}=\frac{2 \pi}{Z_{0}}-\delta_{0} \cong(0,8-0,85) \frac{2 \pi}{Z_{0}}
$$

A tartományon belül a kések egyenletesen vannak felosztva, tehát az osztás értéke 


$$
\tau=\left(\frac{2 \pi}{Z_{0}}-\delta_{0}\right) \frac{1}{z_{s}}
$$

A kések indexei sorban

$$
i \in\{-2 ;-1 ; 0 ; 1 ; 2\}
$$

A nulla indexű kés a referenciakés, mivel a referenciahelyzetet - a késcsoport közepét foglalja el. A kések tájolópontja a generáló fogaslécprofil osztóvonali szakaszának középpontja. A referenciakés tájolópontja és a marófej tengelye közötti távolság a maró $R_{s}$ névleges sugara, ami a görbe fogazat névleges görbületi sugara is egyben.

A késcsoportok kései egyenlő szögtávolságra elhelyezett Arkhimédész-féle spirális vezérgörbén illeszkednek. A spirális emelkedése $Z_{0}$-szor nagyobb, mint a fogasléc osztása, így a vezérspirális poláregyenlete a következő lesz:

$$
\rho(\theta)=R_{s}+\underbrace{\frac{Z_{0} m \pi}{2 \pi}}_{=p_{s p}} \theta
$$

A késcsoport késeinek beállítási sugarai az $i$ index alapján, a (2), (3) és (4) képletek figyelembevételével:

$$
\rho_{i}=R_{s}+i \tau p_{s p}
$$

\section{Az alkalmazott koordináta- rendszerek.}

A matematikai modellt a következő koordináta-rendszerek definiálásával alapozzuk (2. ábra): $S_{0}\left(x_{0} y_{0} z_{0}\right)$ az állványhoz kötött, álló rendszer, $S_{s}\left(x_{s} y_{s} z_{s}\right)$ a szerszámhoz kötött, $S_{1}\left(x_{1} y_{1} z_{1}\right)$ pedig a fogazandó kerékhez kötött koordináta-rendszer. Ezeken kívül mindegyik kés elméleti profiljához csatoljuk az $S_{2}\left(x_{2} y_{2} z_{2}\right)$ koordinátarendszert.

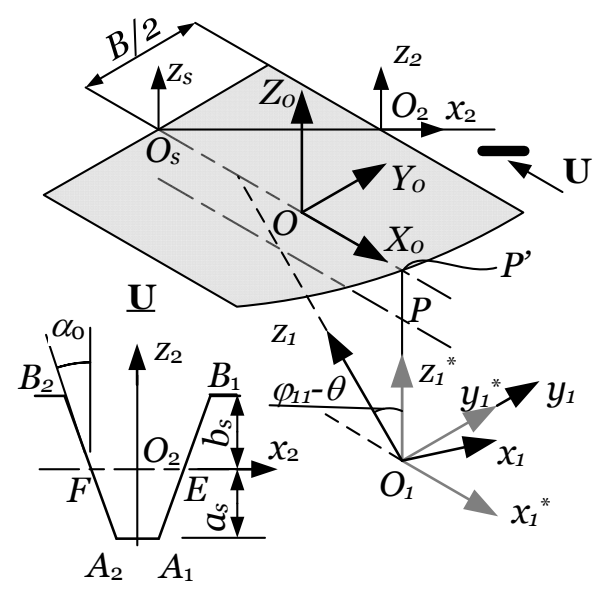

2. ábra. Az alkalmazott koordináta-rendszerek

A fogaskerék $x_{1} z_{1}$ osztósíkja és a rögzített rendszer $X_{0} Z_{0}$ síkja egybeesik. Az $O_{s} O P^{\prime}$ egyenes a virtuális léc osztóvonala. Az ezzel párhuzamos vonal a gördülővonal, a közöttük levő távolság pedig értelemszerüen az $m \xi$ profileltolás. $P$ a virtuális léckerékhajtás pólusa. A fogaskerék $\varphi_{1}$ legördülési szögének nulla értékére a $z_{1}$ tengely áthalad a $P$ póluson ( ${ }^{z_{1}^{*}}$-gal jelöltük). A virtuális lécfogaskerék teljes legördülésének megfelelő szélső szögértékeket egyszerü evolvens geometriai összefüggésekből számítjuk, $\varphi_{1} \in\left[\varphi_{11}, \varphi_{12}\right]$.

$\mathrm{Az}$ elkövetkező számítások kezelését megkönnyíti, ha a legördülési szög határértékeit abszolút értékként kezeljük. Adott legördülési helyzetet a $\theta$ paraméter segítségével definiálunk, $\theta \in\left[0, \varphi_{11}+\varphi_{12}\right]$. A lefejtés adott késcsoport esetében akkor kezdődik el, amikor a késcsoport legelső $(i=-2$ indexü) késének $\mathrm{O}_{2}$ profilközpontja benne van a fogaskerék felső, $y_{1}=B / 2$ határsíkjában. Az $O_{S}$ és $O$ origók távolsága a fogárokba való újabb belépés pillanatában 


$$
O_{s} O(\theta)=r_{d 1}\left(\varphi_{11}-\theta\right)
$$

A tangenciális előtolás paraméterét $s^{*}$ gal jelöljük, ami az egységnyi szerszámszögelfordulásra eső eltolás értékét jelenti.

Az egyes síkokban jelentkező nyomgörbék meghatározásához ismernünk kell az $i_{1 s}$ szerszám-munkadarab áttételi arányt. Ezt a virtuális hajtás kapcsolódási feltételéből írjuk fel, a szögsebességek felhasználásával:

$$
\begin{gathered}
\left(p_{s p}+s^{*}\right) \omega_{s}=r_{d 1} \omega_{1}, \text { ahonnan } \\
i_{1 s}=\frac{\omega_{1}}{\omega_{s}}=\frac{Z_{0}}{z_{1}}+\frac{2 s^{*}}{m z_{1}}
\end{gathered}
$$

\section{A nyomgörbék általános egyen- letei}

\subsection{A nyomgörbeképzés geometriája}

Feltételezzük, hogy a kések élei a marófej forgástengelyén áthaladó síkokban illeszkednek. Könnyen belátható, hogy ez esetben csak az $Y_{0}=0$ központi síkba érkezik egyidejüleg a vizsgált él összes pontja. Az $\alpha_{0}$ lécprofilszögnek köszönhetöen az él különböző pontjai az előbbitől eltérő síkokba egymáshoz viszonyítva késéssel érkeznek, miközben a szerszám halad. A modell akkor hatékony, ha az egyes szeletekben képződő görbék közötti távolságokat is ki tudja fejezni, hogy a későbbiekben a burkolt felület síkszeleteit helyesen lehessen tájolni. Emiatt a (6) egyenlettel megadott tengelytávolság adott $\theta$-ra akkor érvényes, amikor a késcsoport legelső $\rho_{-2}$ sugarú késének $\mathrm{O}_{2}$ profilközpontja az $y=B / 2$ síkba jutott. Az $i$ indexü kés profilközpontjának sugara ehhez képest $(2+i) \tau$ szögnyi késéssel jut el az első kés induló helyzetébe. A levezetésekben szögkompenzációkat kell alkalmaznunk, egyrészt a kések referenciasugarainak különbsége, másrészt a kiválasztott sík helyzete függvényében. Négy esetet tanulmányozunk:

- a konkáv oldali él és a pozitív féltérben levő sík helyzete (3. ábra);

- a konkáv oldali él és a negatív féltérben levő sík helyzete (4. ábra);

- a konvex oldali él és a pozitív féltérben levő sík helyzete (5. ábra);

- a konvex oldali él és a negatív féltérben levő sík helyezte (6. ábra).

\subsubsection{Az i-edik konkáv oldali él pozitív féltérbeli síkba generált görbéjének szögparamétere}

A geometriai viszonyokat a 3. ábrán szemléltettük. A szerszám koordináta-rendszer origóját $O_{s}^{*}$-gal jelöljük, mivel az elfordulási szögek vizsgálatakor a tangenciális előtolást leállítjuk. A valóságban a szerszámközpont elmozdul a tangenciális elötolás és az elfordulási szög szorzatának értékével. A kiválasztott élpont távolsága a szerszámtengelytől az $u$ paraméter függvénye:

$$
\rho_{i}^{(M)}=\rho_{i}+\frac{m \pi}{4}+u \operatorname{tg} \alpha_{0}
$$

Az $O_{s}^{*} O_{2}^{(-2)} S, O_{s}^{*} T Q$ és $O_{s}^{*} \dot{M}^{\prime} P$ háromszögek segítségével felírjuk a konkáv szerszámél kiválasztott $M$ pontjának a pozitív $u_{1}$ paraméterrel tájolt síkba kerüléséhez szükséges elfordulást:

$$
\begin{aligned}
\varepsilon\left(i ; u_{1} ; u\right)= & \arcsin \frac{B}{2 \rho_{-2}}-\arcsin \frac{u_{1}}{2 \rho_{i}^{(M)}}+ \\
& +(i+2) \tau
\end{aligned}
$$

A (8) és (9) egyenletek együttes vizsgálatából következik, hogy az él behatolása a síkba az élcsúccsal kezdődik, és fokozatosan halad az éltő felé, tehát a (9) szög növekszik az $u$ paraméterrel,

$$
u \in\left[-\left(h_{0 a}+c_{0}\right) m, h_{0 a} m\right]
$$




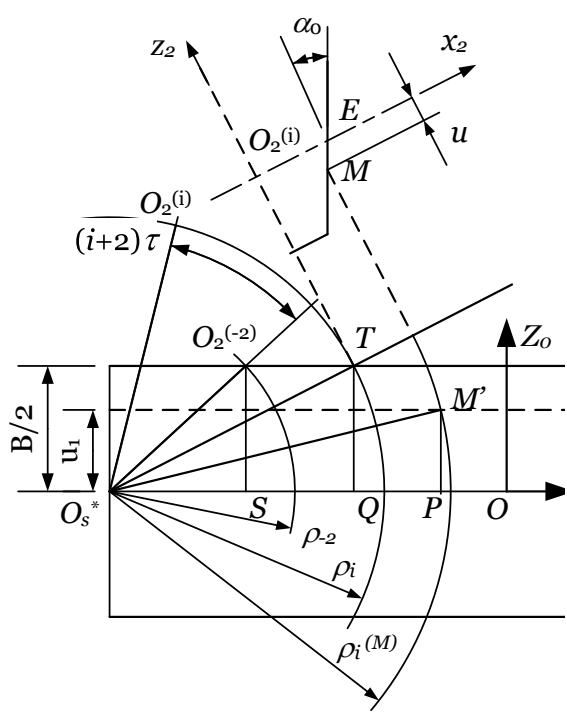

3. ábra. Konkáv oldali nyomgörbe generálása, ha $u_{1}>0$

3.1.2 Az i-edik konkáv oldali él negatív féltérbeli síkba generált görbéjének szögparamétere

A levezetés az előbbi pontban bemutatotthoz hasonló. A geometriai viszonyokat a 4. ábrán szemléltettük. Az $O_{s}^{*} O_{2}^{(-2)} S$, $O_{s}^{*} T Q$ és $O_{s}^{*} P \dot{M}^{\prime}$ háromszögek segítségével felírjuk a $\rho_{i}$ sugárnak az $O_{s}^{*} O_{2}^{(-2)}$ irányra való kerülése és a vizsgált $M$ pont $y=u_{1}, u_{1}<0$ síkba érése között letelt elfordulás szögét:

$$
\begin{aligned}
& v\left(i ; u_{1} ; u\right)=\arcsin \frac{B}{2 \rho_{-2}}-\arcsin \frac{B}{2 \rho_{-i}}+ \\
& +\arcsin \frac{B}{2 \rho_{-i}}+\arcsin \frac{-u_{1}}{\rho_{i}^{(M)}}
\end{aligned}
$$

Ha a (10) kifejezéshez hozzáadjuk az $i$ edik él és az első él közötti szöget, akkor a (9) egyenlettel formálisan azonos egyenletet kapunk. Megfigyelhetö, hogy ez esetben az első élpont, amelyik a vizsgált síkba ér, az él tőpontja, tehát az áthaladás az élcsúcs felé történik, vagyis az élpont sugarának csökkenésével. Ez esetben a kérdéses pont a gyártott fogaskerék tengelyétől távolodik.

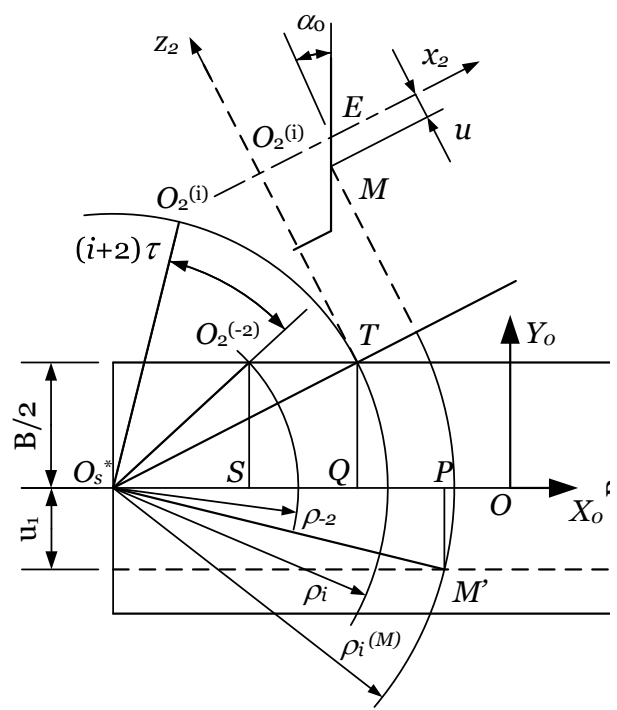

4. ábra. Konkáv oldali nyomgörbe generálása, ha $u_{1}<0$

\subsubsection{Az i-edik konvex oldali él által gene- rált görbe szögparamétere}

A konvex él által generált görbe szögparamétereit az 5. és 6. ábrákon szemléltettük. A számításokat az előbbiekben bemutatott módon végezzük el.

A vizsgált $M$ pont sugarát a

$$
\rho_{i}^{(M)}=\rho_{i}-\left(\frac{m \pi}{4}+u \operatorname{tg} \alpha_{0}\right)
$$

képlettel számítjuk.

\subsection{A nyomgörbék általános egyenle- tei az $S_{0}$ koordináta-rendszerben}

A 3-6 ábrákból észre lehet venni, hogy a vizsgált $M$ pont távolsága a szerszám origótól az $x$ tengely mentén a 


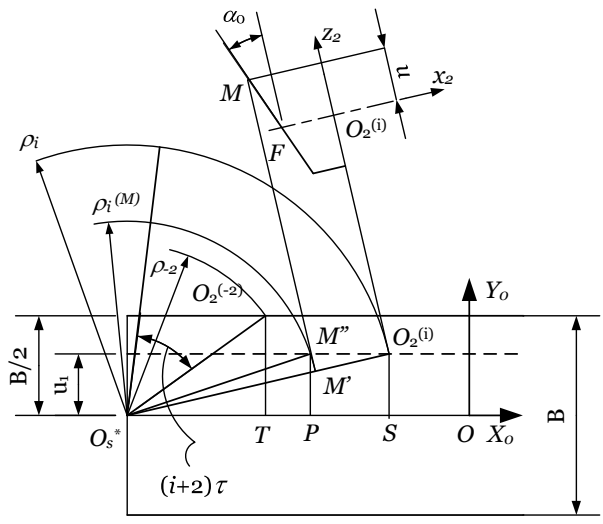

5. ábra. Konvex oldali nyomgörbe generálása, ha $u_{1}>0$

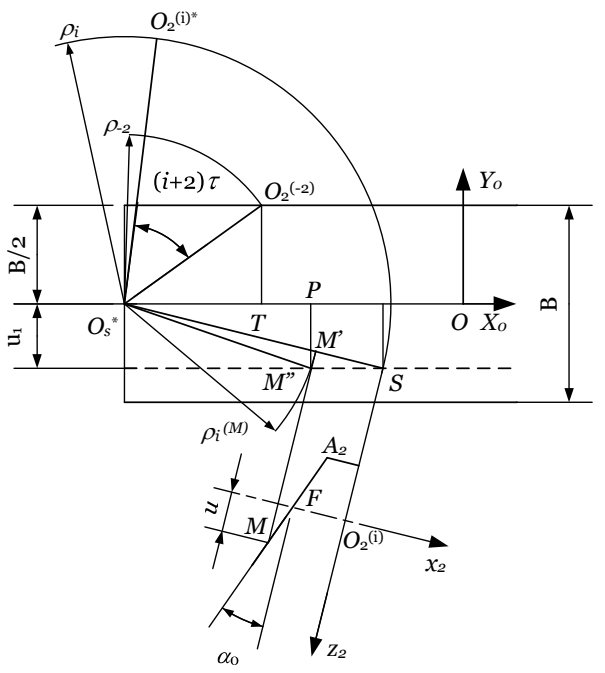

6. ábra. Konvex oldali nyomgörbe generálása, ha $u_{1}<0$

$$
\Delta_{i}^{(M)}=\sqrt{\left[\rho_{i}^{(M)}\right]^{2}-u_{1}^{2}}
$$

képlettel számítható. Figyelembe véve, hogy a szerszámorigó közeledik az álló rendszer origójához, valamint azt, hogy a $z$ irány mentén a vizsgált pont nem mozdul, felírhatók a nyomgörbe álló rendszerbeli parametrikus egyenletei:

$$
\left\{\begin{array}{l}
X_{0}\left(i ; u_{1} ; u\right)=-r_{d 1}\left(\varphi_{11}-\theta\right)+s^{*} \varepsilon\left(i ; u_{1} ; u\right)+\Delta_{i}^{(M)} \\
Y_{0}\left(i ; u_{1} ; u\right)=u_{1} \\
Z_{0}\left(i ; u_{1} ; u\right)=u
\end{array}\right.
$$

\subsection{A nyomgörbék általános egyenle- tei a fogaskerékhez kötött koor- dináta-rendszerben}

A fogaskerék koordináta-rendszere a szerszámfej $\varepsilon\left(i ; u_{1} ; u\right)$ szöggel való elfordulására $i_{1 s} \varepsilon\left(i ; u_{1} ; u\right)$ szöggel fordul el. $\mathrm{Az} 1$. ábrát figyelembe véve, az $S_{1}$ rendszer $x$ tengelyének és az $X_{0}$ iránynak a pillanatnyi szöge

$$
\sigma_{1}=\varphi_{11}-\theta-i_{1 s} \varepsilon\left(i ; u_{1} ; u\right)
$$

Az $S_{0}$-ból az $S_{1}$-be az alábbi koordináta transzformációt alkalmazzuk:

$$
\left\{\begin{array}{l}
\underline{\mathbf{r}}_{1}=\mathbf{M}_{10} \underline{\mathbf{r}}_{0}, \\
\mathbf{M}_{10}=\left(\begin{array}{cccc}
\cos \sigma_{1} & 0 & \sin \sigma_{1} & E_{1} \\
0 & 1 & 0 & 0 \\
-\sin \sigma_{1} & 0 & \cos \sigma_{1} & E_{2} \\
0 & 0 & 0 & 1
\end{array}\right)
\end{array}\right.
$$

Az $E_{1}, E_{2}$ kifejezések a következők:

$$
\begin{aligned}
& E_{1}=-R_{s} \cos \sigma_{1}+\left(r_{d 1}+m \xi\right) \sin \sigma_{1} \\
& E_{2}=R_{s} \sin \sigma_{1}+\left(r_{d 1}+m \xi\right) \cos \sigma_{1}
\end{aligned}
$$

A (13), (14), (15) és (16) képletek egybevetésével fel lehet írni a valós szerszámélek által hagyott nyomgörbéket a fogaskerék tengelyére merőleges síkokban.

\section{Következtetések}

A bemutatott modellen az (1)... (16) képletek a fogprofil középpontjához viszonyítják a nyomgörbék helyzetét, ennek következtében az egyes síkokban keletkezett 
profilok egymáshoz viszonyított távolsága és helyzete nem torzul.

Az álló koordináta-rendszerben levezetett parametrikus egyenletek a virtuális fogasléc síkszelvényeit burkoló véges görbesereget adják. Ki lehet mutatni, hogy a $\theta$ paraméter változtatásával a léc profilja módosul.

\section{Köszönetnyilvánítás}

A kutatás a TÁMOP-4.2.4.A/2-11/12012-0001 azonosító számú Nemzeti Kiválóság Program - Hazai hallgatói, illetve kutatói személyi támogatást biztosító rendszer kidolgozása és müködtetése konvergencia program címü kiemelt projekt keretében zajlott. A projekt az Európai Unió támogatásával, az Európai Szociális Alap társfinanszírozásával valósul meg.

This research was supported by the European Union and the State of Hungary, cofinanced by the European Social Fund in the framework of TÁMOP-4.2.4.A/2-11/12012-0001 'National Excellence Program'.

\section{Szakirodalmi hivatkozások}

[1]Litvin, F.L.: A fogaskerékkapcsolás elmélete. Müszaki Könyvkiadó, Budapest, 1972.

[2] Máté, M., Hollanda, D.: The Cutting of Cylindrical Gears Having Archimedean Spiral Shaped Tooth Line. 13th International Conference on Tools, 27-28 March 2012, Miskolc, ISBN 978-963-9988-35-4, 357-362.

[3]Litvin, F.L., Pin-Hao, F., Lagutin, S.A.:Computerized Generation and Simulation of Meshing and Contact of New Type of NovikovWildhaber Helical Gears, R-2000-209415' [Online].

Available:http://gearexpert.free.fr/fichiers_pd f/engrenage_Novikov_Wildhaber_NASA_re port.pdf [Accessed: 30-Jun-2012]
[4]Nacy, S.M., Abdullah, M.Q., Mohammed, M.N.: Generation of Crowned Parabolic Novikov gears. Adept Scientific Knowledge Base.http://www.adeptscience.co.uk/kb/articl eprint.php?noteid=6E9E. [Accessed: 19-Mar2012].

[5] Dudás, I.: The Theory and Practice of Worm Gear Drives. Penton Press, 2005, ISBN 9781-85718-027-5.

[6] Máté, M., Hollanda, D., Tolvaly-Rosca, F., Popa-Müller, I.: The localization of the contact patch by cylindrical gear having an Archimedean toothline using the method of setting the tangential displacement. XXI-ik OGÉT-2013 - XXI-th International Conference of Mechanical Engineers), Arad, 25-28 apr. 2013, Conference Proceedings, ISSN 2068-1267, 265-268.

[7]Dudas, I., Banyai, K., Varga, G.: Simulation of meshing of worm gearing. American Society of Mechanical Engineers, Design Engineering Division (Publication) DE 88, 141-146,1996.

[8] Varga, G., Balajti, Z., Dudas, I.: Advantages of the CCD camera measurements for profile and wear of cutting tools 2005, Journal of Physics: Conference Series 13 (1), pp. 159162. "Zotero Style Repository," Roy Rosenzweig Center for History and New Media. http://www.zotero.org/styles. [Accessed: 19Mar-2012].

[9] Máté, M.: Hengeres fogaskerekek teherbirásának növelését és hordkép-lokalizációját megvalósitó alternativ lefejtési módszerek elemzése. XIX.- F.M.T.Ü., Kolozsvár, március 20-21. Konferenciakötet, ISSN 20676808, 33-40.

[10] Máté, M., Hollanda, D., Faluvégi, E.: Arkhimédész-féle spirál fogvonalú hengeres fogaskerekek tangenciális elötolásos lefejtésének kinematikája egyparaméteres burkolás esetében. XXII. Nemzetköz Gépész Találkozó, Nagyszeben, 2014.ápr. 24-27. Konferenciakötet, ISSN 2068-1267, 244-247. 